\title{
Warm Climate Production Guidelines for Echinacea 1
}

\section{Dr. Rick Schoellhorn and Alexis A. Richardson ${ }^{2}$}

\section{Echinacea - Celebrate diversity}

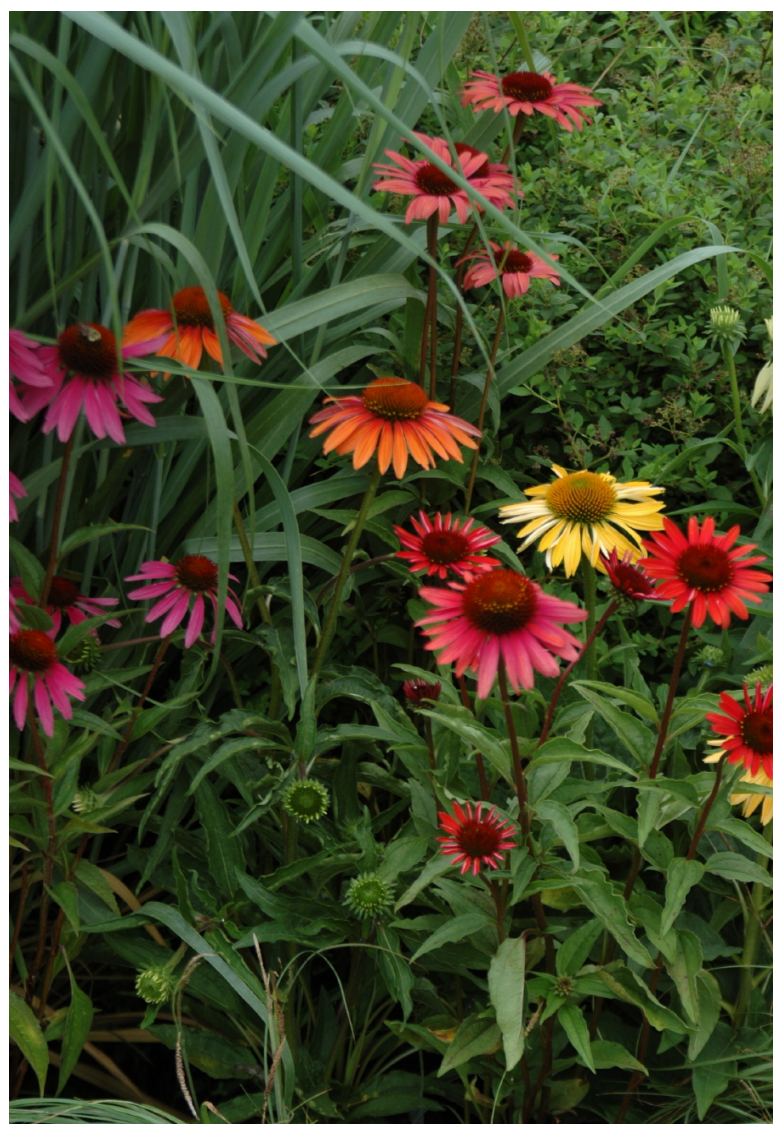

Figure 1. Mixed Echinacea hybrids exhibiting the new color forms being released in 2004-2005. Credits: photo courtesy of ItSaul Plants
This is one of the great moments in time when a renowned but limited perennial flower has the roof blown off of its genetic potential. The advances in Echinacea breeding we will be seeing emerge on the market in the next few years are some of the most exciting changes I've seen a long time. I'm hoping this is the beginning of not only some fantastic new hybrids but also increased awareness of some of the lesser known species.

Magnus has ruled the roost for many years. It is a great seed-produced cultivar (E. purpurea) with strong, purple-toned flowers: a vast improvement over the species. It received the Perennial Plant Association "Plant of the Year" award in 1998. An assortment of purple- to rose- to cerise-toned hybrids have arisen over the years, with some really cool novelty forms popping up in fringe markets as well. It is through the work of Jim Ault at the Chicago Botanic Gardens and Richard Saul of ItSaul plants that we are looking at the release of yellow and orange-toned hybrids that combine striking colors with strong performance. The release of these new lines indicates that we will soon be seeing all the other shades of color between red and yellow on the market in the next few years.

1. This document is ENH 993, one of a series of the Environmental Horticulture Department, Florida Cooperative Extension Service, Institute of Food and Agricultural Sciences, University of Florida. Original publication date November 11, 2004. Please visit the EDIS web site at http://edis.ifas.ufl.edu.

2. Rick Shoellhorn, associate professor, commercial floriculure specialist; Alexis A. Richardson, contributing writer; Environmental Horticulture Department, Institute of Food and Agricultural Sciences, University of Florida, Gainesville FL 32611.

The Institute of Food and Agricultural Sciences is an equal opportunity/affirmative action employer authorized to provide research, educational information and other services only to individuals and institutions that function without regard to race, color, sex, age, handicap, or national origin. For information on obtaining other extension publications, contact your county Cooperative Extension Service office. Florida Cooperative Extension Service/Institute of Food and Agricultural Sciences/University of Florida/Christine Taylor Waddill, Dean. 


\section{ItSaul Plants}

Richard Saul has been breeding Echinacea for about ten years, and the releases coming out of the ItSaul program are revolutionary. Scheduled for release in early 2005 are two cultivars in the Big Sky series. 'Sunrise'PPAF is a clear pale citron yellow and 'Sunset' ${ }^{\mathrm{PPAF}}$ is a strong orange. For release late in 2005 (summer or fall) is 'Twilight' ${ }^{\text {'PAF }}$, a rose with a red cone. The flowers of these newer rose-toned hybrids are actually a lot of different iridescent tones and a little hard to describe, but truly beautiful! For 2006 and later, be looking for bi-colors, dark yellows, peach, coral and other intermediate shades. Saul's releases are crosses between Echinacea purpurea and E. paradoxa, but the Big Sky Series resembles E. purpurea with broad, deep-green leaves, overlapping petals, and multiple blooms. The Big Sky Series is coming out of tissue culture and is only available as a vegetative liner. A variety of plug producers are licensed to propagate both 'Sunset' and 'Sunrise,' but there is likely not going to be enough of this crop to go around the first year, so place orders early. The Big Sky series has a long shelf life as a cut flower and is fragrant as well.

\section{The Chicago Botanic Gardens}

Jim Ault with The CBG also released the first of their new hybrids in 2004. The Meadowbrite Series ${ }^{\mathrm{TM}}$ beginning with 'Orange Meadowbrite ${ }^{\text {PPAF }}$ is emerging in exclusive catalogs and select nurseries (See suppliers listings below). The flower is a strong orange tone with more the leaf type of its E. paradoxa parents. That means the leaves are thinner and more strap-like and flower petals are slightly separated. 'Mango Meadowbrite' ${ }^{\text {PPAF }}$ is a yellow-toned release. Lots of colors including the elusive rose tones are coming in 2005 and beyond. It's the same story for the Chicago releases as for the Big Sky Series: supplies are limited and many suppliers are already sold out.

\section{Other Great Novelty Types}

It was an amazing discovery to see what is out in the industry as novelty forms of this crop. My knowledge of potential cultivars went from about 5 to over 25 colors and forms I had not heard of before researching this article, and I learned about many seed-produced forms including Benary Seeds' 'Primadonna Deep Rose.' The truly strange vegetative forms were also amazing. I encourage anyone who wants to learn more about these unusual forms to look for 'Doppelganger,' a form with petals erupting from the top of the cones giving each blossom a "mop head" and doubling the color impact of the flower. Another form, 'Double-decker,' is just what its name implies, with secondary flowers arising from the cone of the lowest bloom on the stalk. This hybrid looks a bit like a Leonotus, with stacked flowers on each stalk. 'Razzmatazz' is what chrysanthemum producers would call an anemone form, with small petals entirely encasing the cone of the flower so that it appears double, but all the inner petals are quite small. 'Prairie Frost' and 'Sparkler' are both variegated types with single flowers, but the variegation is quite different in each case. The variegated forms of Echinacea may need a little more shade to protect the leaves from scorching under high light. They are also a little less vigorous than their green-leaved counterparts.

\section{Commercial Production Guidelines for Echinacea}

Fertilization $-75-150 \mathrm{ppm}$ nitrogen is usually sufficient. Avoid high ammonium forms as they will weaken stems and elongate leaves.

Watering - Normal production irrigation is fine.

$\underline{\text { Media }}$-All commercial peat lite media and bark peat mixtures work fine, $\mathrm{pH}$ optimum 5.5 to 7.0 for most cultivars. Slightly alkaline media are tolerated by many cvs.

Production Temperatures -Temperatures of $50-60^{\circ} \mathrm{F}$ night and $70-75 \mathrm{~F}$ daytime are adequate. Cooler temperatures as flowers color up will also give deeper color to the blooms.

$\underline{\text { Light level - High light or over } 1000 \mu \mathrm{mol} \mathrm{m}}{ }^{-2}$ $\mathrm{s}^{-1}$, for most green leaved cultivars, however variegated types may need lower light levels to avoid scorching.

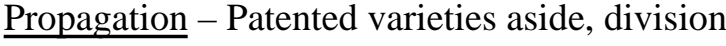
and softwood cuttings are easy to grow, but most growers go for uniformity of either seed or vegetative liners. 
Crop timing - Plan on about 6 months from seed to flower. From liner to sale it depends on the time of year, but around 6 weeks for quarts and 8 weeks for gallons.

Growth regulators - For those of you more comfortable with Daminozide (5,000 ppm), or Daminozide and Chlormequat tank mixes $(5,000$ $\mathrm{ppm} / 1500 \mathrm{ppm}$ ) you can use them, but you will need to do multiple applications and you must stop as flowers emerge so you aren't reducing flower size. For growers more comfortable with Paclobutrazol, a $30 \mathrm{ppm}$ drench, or repeated $30 \mathrm{ppm}$ sprays will work. Uniconazole will be less than 30 ppm for sprays, but remember the rates. Also, cultivars will all perform differently depending on where you are in the country, so do your own tests on which PGR works best for you.

Flowering - A note about vernalization - Most suppliers state that Echinacea do not require vernalization, but all will tell you $4-8$ weeks at $40^{\circ} \mathrm{F}$ will give you a faster crop with more uniform flowering. That sure sounds like vernalization to me!

This crop has such an interesting history of a market as a perennial, expanding into a market for medicinal use and now an explosion of new colors. The future of Coneflowers will never be quite the same.

\section{Commercial Sources for Echinacea}

Jackson and Perkins - http://www.jproses.com

Monrovia Nurseries - http://www.monrovia.com

ItSaul Plants - http://www.cone-crazy.com

Yoder Brothers/ Greenleaf Perennials http://www.yoder.com

Purdue University has a nice description of native forms and species at: http://www.hort.purduE.edu/newcrop/ncnu02/v5506.html

Sunny Border Nurseries http://www.sunnyborder.com
Wayside Gardens -

http://www.waysidegardens.com

Plant Delights - http://www.plantdelights.com 
Table 1. Cultivar Information

\begin{tabular}{|c|c|c|c|c|}
\hline Cultivar & Suppliers & Liner & Color & Height \\
\hline Abendsonne & Many & Seed & Cerise Pink & $32-36$ inches \\
\hline Alba & Many & Seed-Veg & Creamy White & 36 inches \\
\hline Big Sky Sunrise ${ }^{\text {PPAF }}$ & ItSaul Plants & Veg & Yellow & 34-36 inches \\
\hline Big Sky Sunset ${ }^{\text {PPAF }}$ & ItSaul Plants & Veg & Orange & $24-30$ inches \\
\hline Bravado & Many & Veg & Rosy Red & 24-30 inches \\
\hline Bressingham Hybrids & Many & Seed & Rose-Red & $32-36$ inches \\
\hline Bright Star & Many & Seed & Rose-Red & 26-36 inches \\
\hline Crimson Star & Many & Seed-Veg & Crimson-Rose & 30-36 inches \\
\hline Dwarf Star & Many & Seed & Rose & $12-24$ inches \\
\hline Fragrant Angel & Canning Perennials & Veg & White & 30 inches \\
\hline Kim's Knee High & Sunny Border Nurseries & Seed & Purple-Rose & $12-18$ inches \\
\hline Kim's Mophead & Sunny Border Nurseries & Seed & White & $12-18$ inches \\
\hline Little Giant & Canning Perennials & Veg & Rose-Red & 12 inches \\
\hline Magnus & Many & Seed & Rose Pink & 30-36 inches \\
\hline Mango Meadowbrite ${ }^{\text {PAF }}$ & Wayside Gardens & Veg & Yellow & 36 inches \\
\hline Orange Meadowbrite ${ }^{\text {PPAF }}$ & Wayside Gardens & Veg & Orange & 36 inches \\
\hline Overton & Many & Seed & Rose Pink & 24-30 inches \\
\hline Paranoia & Plant Delights & Veg & Yellow & 12 inches \\
\hline Primadonna & Benary Seed & Seed & Deep Rose & $32-36$ inches \\
\hline Robert Bloom & Many & Seed & Purple -Rose & 36 inches \\
\hline Ruby Star & Many & Seed & Crimson-Rose & 30-36 inches \\
\hline The King & Many & Seed & Rose-Red & $48-52$ inches \\
\hline Vintage Wine & Many & Seed & Rose-Red & 36 inches \\
\hline White Lustre & Many & Seed & White & 36 inches \\
\hline White Swan & Many & Seed & White & 36 inches \\
\hline Novelty Forms & Trait & Liner & Color & Height \\
\hline Ruby Giant & 7-inch flowers & Veg & Rose-Red & 24-30 inches \\
\hline Doppelganger & Tufted petals arise from top to disc & Veg & Purple-Rose & 30-36 inches \\
\hline Double Decker & $\begin{array}{l}\text { Flower over flower, like a } \\
\text { double-decker bus }\end{array}$ & Veg & Purple-Rose & $30-36$ inches \\
\hline Prairie Frost & Variegated foliage & Veg & Purple-Rose & 24-32 inches \\
\hline Razzmatazz & $\begin{array}{l}\text { Anemone type disc covered in small } \\
\text { petals }\end{array}$ & Veg & Purple-Rose & 30-34 inches \\
\hline Sparkler & $\begin{array}{l}\text { Spotted variegation, to bright white } \\
\text { foliage }\end{array}$ & Veg & Pink-Rose & 24-28 inches \\
\hline \multicolumn{5}{|c|}{$\begin{array}{l}\text { Species: E. angustifolia, E. atrorubens, E. laevigata, E. pallida, E. paradoxa, E. purpurea, E. sanguinea, E. simulata, E. } \\
\text { tennesseensis }\end{array}$} \\
\hline
\end{tabular}

